\title{
Dissolved fulvic acids from a high arsenic aquifer shuttle electrons to enhance microbial iron reduction
}

\author{
Harshad V. Kulkarni ${ }^{1}$, Natalie Mladenov ${ }^{2 *}$, Diane M. McKnight ${ }^{3}$, Yan Zheng ${ }^{4,5}$, Matthew Kirk ${ }^{6}$, \\ Diana R. Nemergut ${ }^{3,7}$ \\ ${ }^{1}$ Department of Civil Engineering, Kansas State University, 2118 Fiedler Hall, Manhattan, KS, \\ USA 66506 \\ ${ }^{2}$ Department of Civil, Construction and Environmental Engineering, San Diego State University, \\ San Diego, CA, USA 92182 \\ ${ }^{3}$ INSTAAR, University of Colorado at Boulder, Boulder, CO, USA 80302 \\ ${ }^{4}$ School of Environmental Science and Engineering and Shenzhen Key Laboratory of Soil and \\ Groundwater Pollution Control, Southern University of Science and Technology, Shenzhen, \\ China 518005 \\ ${ }^{5}$ Lamont-Doherty Earth Observatory, Columbia University, Palisades, NY, USA 10964 \\ ${ }^{6}$ Department of Geology, Kansas State University, Manhattan, KS, USA 66502 \\ ${ }^{7}$ Department of Biology, Duke University, Durham, NC, USA 27708 (deceased) \\ *Correspondence to: Natalie Mladenov \\ E-mail: nmladenov@sdsu.edu \\ Tel: 619-594-0725 \\ Fax: 619-594-6005 \\ Mailing address: 5500 Campanile Drive, San Diego, CA, 92182
}

\begin{abstract}
It was demonstrated more than two decades ago that microorganisms use humic substances, including fulvic acid (FA), as electron shuttles during iron (Fe) reduction in anaerobic soils and sediments. The relevance of this mechanism for the acceleration of Fe(III) reduction in arsenic-laden groundwater environments is gaining wider attention. Here we provide new evidence that dissolved FAs isolated from sediment-influenced surface water and groundwater in the Bengal Basin were capable of electron shuttling between Geobacter metallireducens and $\mathrm{Fe}(\mathrm{III})$. Moreover, all four Bangladesh sediment-derived dissolved FAs investigated in this study had higher electron accepting capacity (176 to $245 \mu \mathrm{mol} / \mathrm{g}$ ) compared to aquatic FAs, such as Suwanee River Fulvic Acid $(67 \mu \mathrm{mol} / \mathrm{g})$. Our direct evidence that Bangladesh FAs are capable of intermediate electron transfer to Fe(III) supports other studies that implicate electron shuttling by sediment-derived aqueous humics to enhance Fe reduction and, in turn, As mobility. Overall, the finding of greater electron accepting capacity by dissolved FAs from groundwater and other sediment-influenced environments advances our understanding of mechanisms that control $\mathrm{Fe}$ reduction under conditions where electron transfer is the rate limiting step.
\end{abstract}

(C) 2018. This manuscript version is made available under the CC-BY-NC-ND 4.0 license http://creativecommons.org/licenses/by-nc-nd/4.0/

\section{Introduction}

Microbial reductive dissolution is a globally relevant mechanism that dissolves poorly soluble iron (Fe) minerals into soluble Fe(II) (McArthur et al., 2001; Dowling et al., 2002; Hasan et al., 2007). 
This leads to the mobilization of other ecologically- and toxicologically-important elements, such as arsenic (As). Indeed, Fe reduction is directly implicated in the mobilization of geogenic arsenic in reducing Holocene aquifers of the Bengal Basin. Twenty million people in Bangladesh (Flanagan et al., 2012) and >4 million people in eight highly affected districts of West Bengal, India (Chakraborti et al., 2009) are estimated to drink well water with As concentrations that exceed the national standard of $50 \mu \mathrm{g} / \mathrm{L}$.

It is widely accepted that labile organic matter (OM) drives microbial Fe reductive dissolution of $\mathrm{Fe}$ and As mobilization (Nickson et al., 1998; McArthur et al., 2001; Dowling et al., 2002; Hasan et al., 2007). Recent studies have suggested that a more recalcitrant class of dissolved OM, namely humic substances, also present in reducing groundwater may have an important role in As mobilization. It has been hypothesized that dissolved humics (humic DOM) can serve to shuttle electrons and enhance the reductive dissolution of $\mathrm{Fe}($ oxy)hydroxide minerals (Figure 1), accelerating the mobilization of dissolved arsenic in Bengal Basin aquifers (Mladenov et al., 2010, 2015; Chen et al., 2017).

Seminal work by Lovley et al. (1996) has demonstrated that a model humic compound, anthraquinone-2, 6-disulfonate (AQDS) was capable of serving as an electron acceptor in the oxidation of acetate by Geobacter metallireducens, and, once reduced could abiotically reduce both dissolved and solid-phase Fe(III). Scott et al. (1998) showed that quinone moieties in dissolved humics were involved in electron shuttling in natural environments. The loss of electrons in the reduction of $\mathrm{Fe}(\mathrm{III})$, thereby, regenerates the quinone moieties so that these humic substances can continue to cycle electrons, even at low concentrations (Lovley et al., 1996). Subsequent studies further showed that dissolved humics were capable of shuttling electrons from a wide range microorganism, including Firmicutes, Chloroflexi and $\alpha, \beta, \delta, \gamma$-Proteobacteria (Lovley et al., 1999; Holmes et al., 2004; Wrighton et al., 2008), to electron acceptors, such as $\mathrm{Fe}(\mathrm{III})$, under reducing conditions. Recent studies also support that electron shuttling by natural humic substances occurs at varying concentrations of dissolved FA, ranging from $1 \mathrm{mg} / \mathrm{L}$ (Wolf et al., 2009) to $10 \mathrm{mg} / \mathrm{L}$ (Jiang and Kappler, 2008), and has been demonstrated for solid phase humic substances as well (Kappler et al., 2004; Roden et al., 2010).

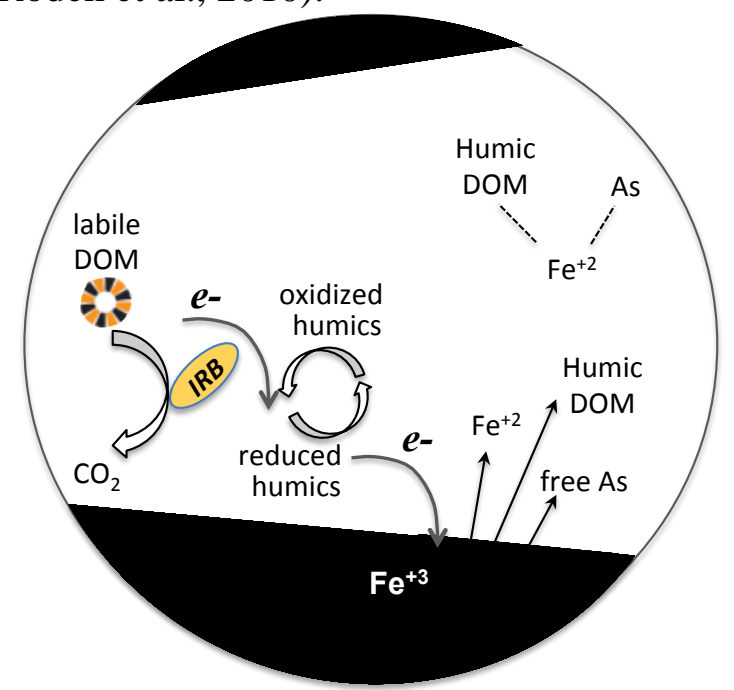

Figure 1. Conceptual model showing a revised hypothesis of humics- enhanced microbial reductive dissolution by iron reducing bacteria (IRB) in which dissolved humics (humic DOM) serve as electron shuttles to accelerate $\mathrm{Fe}$ (II) release and mobilization of As into solution. The resulting increase in concentrations of free $\mathrm{Fe}(\mathrm{II})$ allows for greater complexation of $\mathrm{Fe}$ with other molecules (e.g., DOM and As ternary complex with $\mathrm{Fe}$ ), which lowers the activity of free $\mathrm{Fe}$ (II) and diminishes surface complexation by Fe(II). Precipitation and competitive sorption reactions are not shown.

Sediments are an important source for dissolved FA in Bangladesh aquifers (Mladenov et al., 2010; Reza et al., 2010). Indeed, sediments have been shown to release DOM in incubation studies 
(Mladenov et al., 2010; Neumann et al., 2014). Mladenov et al. (2015) determined that the concentrations of Bangladesh fulvic acids (BFAs) isolated from groundwater in low-sulfate reducing aquifers in Bangladesh were significantly related to both dissolved $\mathrm{Fe}$ and As concentrations at the same site, suggesting that the amount of BFA in groundwater was a key factor influencing $\mathrm{Fe}$ and As mobility in this setting. The authors hypothesized that, under the conditions representative of their site (low dissolved sulfate, reducing conditions, and sufficient supply of labile electron donor and acceptor), fulvic acids were involved in electron shuttling reactions that could substantially increase dissolved Fe and As concentrations (Mladenov et al., 2010, 2015). Most recently, Chen et al. (2017) provided compelling evidence for the role of electron shuttles in arsenic mobilization in reducing aquifers. The authors added AQDS (humic analog) and acetate (the primary electron donor) to arsenic rich sediment in China and found that As(III) concentrations increased by an order of magnitude compared to additions with only acetate.

Although these studies support the concept that native humic shuttles accelerate $\mathrm{Fe}$ reductive dissolution, it still remains to be demonstrated whether fulvic acids isolated directly from those reducing groundwater environments can shuttle electrons to accelerate $\mathrm{Fe}$ reduction. For humic DOM from groundwater of the Bengal Basin to be involved in Fe reductive dissolution reactions as electron shuttles, it must be demonstrated that these humic substances have substantial electron accepting capacity. Here, we isolated four fulvic acids (BFAs) from large volume water samples from a high-As Holoceneaged aquifer in Bangladesh. Three of the BFAs are from groundwater that contained varying amounts of dissolved $\mathrm{As}, \mathrm{Fe}$, and sulfate concentrations, and one BFA is from a groundwater-fed river (KSW) near Araihazar, Bangladesh (Mladenov et al.,
2015). We evaluated their electron accepting capacities using a previously described (Lovley et al., 1996; Scott et al., 1998), twostep experiment in which 1) the BFAs accept electrons from Geobacter metallireducens and, 2) after filter sterilization, the BFAs transfer electrons to dissolved $\mathrm{Fe}(\mathrm{III})$. For comparison, experiments were also performed with two well-studied organic shuttles, the Suwannee River Fulvic Acid (SRFA), a fulvic acid isolated from a river draining an extensive wetland and available from the International Humic Substances Society (IHSS), and the humic quinone analog, anthraquinone-2,6disulfonate (AQDS), which reduces to anthrahydroquinone-2,6-disulfonate

(AHDS). Based on experimental results, electron accepting capacities were calculated for each FA and compared to those reported for other humic and fulvic acids in the literature.

\section{Materials and Methods}

Fulvic acid isolation and preparation

Large volume ( 215 L) samples were collected for fulvic acid isolation from three groundwater sampling sites and one surface water site near Araihazar upazila, Bangladesh, located approximately $30 \mathrm{~km}$ northeast of Dhaka, Bangladesh. Chemical characteristics of the bulk groundwater and of the isolated BFAs were described in detail in Mladenov et al. (2015). Briefly, samples K12.1 and K10.2 collected at $7.5 \mathrm{~m}$ and $11 \mathrm{~m}$ depths, respectively, were identified with groundwater ages of less than 5 years, while sample K8.3 collected at a depth of $14.8 \mathrm{~m}$ was found to be older than 30 years (Mladenov et al., 2015). FA samples $\mathrm{K} 12.1, \mathrm{~K} 10.2$, and $\mathrm{K} 8.3$ are from groundwater containing varying amounts of dissolved As $(2,69$, and $363 \mu \mathrm{g} / \mathrm{L}$, respectively), $\mathrm{Fe}(0.5,3.5$ and $11 \mathrm{mg} / \mathrm{L}$, respectively), and sulfate $(10.7,14.7$, and $0.05 \mathrm{mg} / \mathrm{L}$, respectively) concentrations. FA sample KSW is from the Old Brahmaputra River near site K8.3 (Mladenov et al., 2015) 
and its radiocarbon age was reported as 835 \pm 15 years (Simone, 2010).

The large volume samples were transported to University of Dhaka, Bangladesh, where they were acidified, filtered and pumped through pre-cleaned XAD-8 resin columns to extract the hydrophobic organic acid (fulvic acid) fraction. The columns were back-eluted with base, and eluates were collected, acidified again, and shipped to University of Colorado for final desalting, cation exchange and freeze-drying. A detailed description of the FA isolation process is described in Mladenov et al. (2015). Fulvic acid isolates from K8.3 were found to be relatively more terrestrially-derived (lower fluorescence index) and aromatic (highest aromatic to aliphatic ratio) and with the lowest protein-like fluorescence of all the BFAs (Mladenov et al., 2015). Other humic substances used in electron shuttling experiments included AQDS (commerciallyavailable, Aldrich) and SRFA, which is a FA isolated from the Suwannee River, which drains the Okeefenokee Swamp (available from the IHSS \# 2S101H).

Fulvic acids were dissolved in 18.2 $\mathrm{M} \Omega-\mathrm{cm}$ Milli-Q ultra-pure water to obtain final concentrations of $2 \mathrm{~g} / \mathrm{L}$. Nutrients ATCC $^{\circledR} 1768$ (Lovley et al., 1993), except ferric citrate, $\mathrm{pH}$ 6.8) were added and dissolved in the BFA solutions in appropriate amounts. Industrial grade $\mathrm{N}_{2}$ gas was bubbled through the BFA solutions for $1 \mathrm{~h}$ in $18 \mathrm{~mm} \times 150 \mathrm{~mm}$ glass test tubes, and tubes were sealed under $\mathrm{N}_{2}$ headspace with $20 \mathrm{~mm}$ blue butyl rubber stopper and aluminum seal.

\section{Propagation of Geobacter metallireducens}

As described in Lovley et al. (1993), Geobacter metallireducens $\quad\left(\mathrm{ATCC}^{\circledR}\right.$ $53774^{\mathrm{TM}}$ ) pure culture and freshly prepared ferric citrate medium $\left(\right.$ ATCC $^{\circledR}$ 1768) were used for propagating the cells. The $\mathrm{pH}$ of the medium was maintained between 6.8 and
7.0 after bubbling $80 \% \mathrm{~N}_{2}$ and $20 \% \mathrm{CO}_{2}$. As per the $\mathrm{ATCC}^{\circledR} 53774^{\mathrm{TM}}$ propagation protocol, frozen vials of the pure culture were thawed under anaerobic conditions and an aliquot of pure culture was transferred into previously prepared $10 \mathrm{ml}$ aliquots of ferric citrate $(55 \mathrm{mM})$ medium in sealed anaerobic test tubes by sterilized needle. After $7 \mathrm{~d}$ incubation, a $0.5 \mathrm{~mL}$ aliquot from the first test tube was transferred to the second, and three such transfers were made, one every $7 \mathrm{~d}$ to grow sufficient cells for the experiment.

\section{Successive filtration to wash bacterial} cells

Prior to conducting electron accepting experiments, traces of $\mathrm{Fe}$ were removed from the medium and cells. A successive filtration process was used to isolate the bacterial cells (Figure S1) from the ferric citrate medium (ATCC ${ }^{\circledR}$ 1768). The efficiency of this method was monitored by measuring $\mathrm{Fe}(\mathrm{II})$ at every filtration stage (Table S1). From the culture, $5 \mathrm{ml}$ was filtered through a $0.2 \mu \mathrm{m}$ nylon sterile syringe filter, pre-rinsed with $20 \mathrm{ml}$ of anaerobic ( $\mathrm{N}_{2}$ purged) $18.2 \mathrm{M} \Omega-\mathrm{cm}$ Milli-Q ultra-pure water. The filtrate (waste) contained the medium constituents and microbially-produced $\mathrm{Fe}(\mathrm{II})$, and trace amounts of ferric citrate with bacterial cells were retained on the filter. This filter was then backwashed using $2 \mathrm{~mL}$ of ultra-pure water to collect bacterial cells. To this, $3 \mathrm{~mL}$ of ultra-pure water was added and a total 5 $\mathrm{mL}$ volume was again filtered through a new filter. This process was successively repeated four times to remove any traces of $\mathrm{Fe}(\mathrm{II})$, which was confirmed by $\mathrm{Fe}(\mathrm{II})$ measurement (Table S1) by Ferrozine assay (Stookey, 1970). At the end of fifth backwash, $400 \mu \mathrm{L}$ of solution containing bacterial cells was added to $1 \mathrm{~mL}$ of 2 $\mathrm{mg} / \mathrm{mL}$ BFA medium for inoculation.

Electron shuttling experiment 
The electron shuttling experiment was conducted in two steps as previously described in Lovley et al. (1996). In the first step of the experiment, bacteria oxidize labile OM with oxidized FA as the electron acceptor. In the second step, the reduced FAs from step (1) abiotically transfer electrons to $\mathrm{Fe}$ (III) (Figure 2). In the first step, $400 \mu \mathrm{L}$ of solution containing "washed" G. metallireducens cells was added to $1 \mathrm{~mL}$ of $2 \mathrm{mg} / \mathrm{mL}$ BFA, SRFA, or AQDS and medium containing labile DOM (acetate) in test tubes under strict anaerobic conditions ( 0 ppm $\mathrm{O}_{2}$; Figure 2), and at room temperature $\left(\sim 25^{\circ} \mathrm{C}\right)$. Very low dry mass of isolated BFAs precluded replicate experiments for each sample. Only BFA sample K12.1 had sufficient FA mass to perform triplicate experiments.

After $7 \mathrm{~d}$ incubations, filtrates containing reduced FAs and AHDS (reduced form of AQDS) were filter-sterilized (0.2 $\mu \mathrm{m})$ to remove bacterial cells and ensure that only reduced FAs are involved in the second step of the experiment (Figure 2). In the second step, a $0.5 \mathrm{~mL}$ filtrate aliquot was added to $0.5 \mathrm{~mL}$ of $55 \mathrm{mM}$ freshly prepared ferric citrate solution in a $1.5 \mathrm{~mL}$ microcentrifuge tube and, after a reaction period of up to $4 \mathrm{~h}$, the sample was analyzed for $\mathrm{Fe}(\mathrm{II})$ concentration using the ferrozine method (Stookey, 1970). Absorbance measurements for $\mathrm{Fe}$ (II) were performed in triplicate for all reacted samples. In a control experiment following the same protocol, non-reduced SRFA was reacted with Fe(III) in the presence and absence of acetate. The non-reduced SRFA produced negligible $\mathrm{Fe}(\mathrm{II})$ upon reaction with $\mathrm{Fe}(\mathrm{III})$ (Supplementary Table S2). Additional control experiments using non-reduced BFAs could not be performed due to insufficient amounts of BFAs. Only for microbially-reduced K12.1 BFA, there was sufficient mass to conduct reactions with ferric citrate over $0.25 \mathrm{~h}, 2 \mathrm{~h}$, and $4 \mathrm{~h}$ to ensure that concentrations of $\mathrm{Fe}(\mathrm{II})$ produced at $0.25 \mathrm{~h}$ were similar to those at 4 $\mathrm{h}$ and to ensure that there was sufficient time for all the reduced BFA to react with ferric citrate.

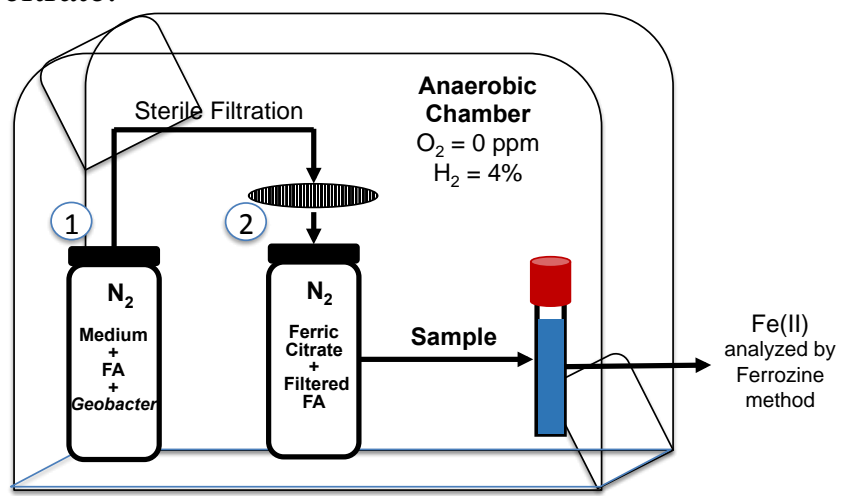

Figure 2. Procedure to (1) microbially reduce Bangladesh Fulvic Acid and other fulvic acids and (2) react filter sterilized reduced FA solution with ferric citrate under strict anaerobic conditions ( $\mathrm{N}_{2}$ atmosphere). Concentration of $\mathrm{Fe}(\mathrm{II})$ produced is measured using the Ferrozine method.

\section{Results and Discussion}

A two-step electron accepting capacity experiment, following Lovley et al. (1996), was performed to simulate electron shuttling by humics in natural environments. This ex-situ experimental setup is necessary to directly demonstrate the microbial reduction of FA and subsequent abiotic electron transfer by FAs, which results in regeneration of the oxidized FA. After native BFAs, SRFA, and AQDS were reduced by $G$. metallireducens and filtersterilized solution was reacted with ferric citrate, we found that all reduced BFAs were able to subsequently reduce $\mathrm{Fe}$ (III) to $\mathrm{Fe}(\mathrm{II})$ (Figure $3 \mathrm{a}$ and $3 \mathrm{~b}$ ). By contrast, our controls with non-reduced SRFA (not exposed to labile $\mathrm{OM}$ and microorganisms) produced only negligible amounts of $\mathrm{Fe}$ (II) $(\sim 3$ $\mu \mathrm{mol} / \mathrm{g}$; Supplementary Table S2). Although replicate experiments could not be performed for each BFA sample, in the case of sample K12.1, there was enough FA available to perform three separate reactions at different abiotic reaction times as shown in Table S2. The Fe(II) concentrations 
produced from each of the three reactions with K12.1 BFA were similar (Supplementary Table S3), with an average electron accepting capacity of $169.8 \pm 8.1$ $\mu \mathrm{mol} / \mathrm{g}$. Moreover, electron accepting capacities of the three BFAs were in close agreement with each other, lending further support for the experimental procedures.

In earlier laboratory-based studies, the role of humic substances as intermediate electron acceptors in the microbial respiration of iron, sulfate and nitrate has been well established (Lovley et al., 1996, 1998 and 1999; Scott et al., 1998). In this study, we show for the first time that fulvic acids isolated directly from groundwater and a groundwater-fed river in Bangladesh are capable of being used by G. metallireducens to shuttle electrons to aqueous Fe(III). Our results demonstrate that, not only were the reduced BFAs able to shuttle electrons to $\mathrm{Fe}(\mathrm{III})$, but the electron accepting capacities of all BFAs were much higher (ranging from $176 \mu \mathrm{mol} / \mathrm{g}$ to $245 \mu \mathrm{mol} / \mathrm{g}$ ) than for SRFA or AQDS (at 67 and $135 \mu \mathrm{mol} / \mathrm{g}$, respectively; Figure 3a and Supplementary Table S2). We found the electron accepting capacity of our SRFA sample (Supplementary Table S2) to corroborate that reported in Lovley et al. (1996), Scott et al. (1998), and Jiang and Kappler (2008). Also, all BFAs had electron accepting capacities that were $\sim$ threefold higher than those of Lake Fryxell FA (LFFA, from an ice-covered Antarctic lake in a watershed devoid of plants; Aiken et al., 1996). The SRFA and LFFA represent two endmembers in terms of the contribution of plant-derived precursor OM to aquatic FA formation.

Our results suggest that the higher electron accepting capacity in our sedimentinfluenced groundwater and surface water fulvic acids may be due to the influence of sedimentary sources.

The electron accepting capacities of all BFAs were most similar to those of two previously studied FAs isolated from extracts of marine and freshwater surficial sediments (SDFA from San Diego Bay and NLFA from a small alpine lake, Nymph Lake) (Scott et al., 1998). Similarly, humic substances extracted from soil or sediments were previously found to have significantly higher electron accepting capacity than FAs isolated from aquatic environments (Lovley et al., 1996). Although humic acids were not isolated for this study, based on the even higher electron accepting capacities for soil humic acids from the literature (Figure 3a and Supplementary Table S1), we expect that sedimentary humic acids (Roden et al., 2010) will also have a significant role in Bangladesh aquifers.
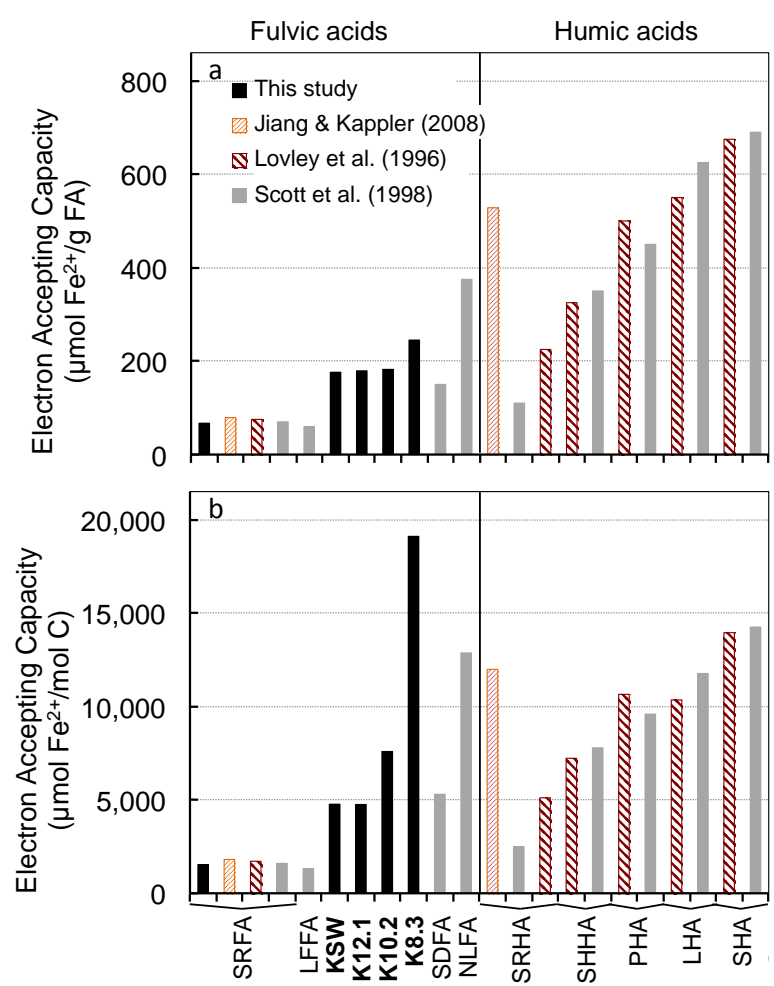

Figure 3. Electron accepting capacities per gram of fulvic or humic acid (a) and per mole of carbon (b), measured using the method of Lovley et al. (1996) for Bangladesh FAs in this study (black) and FAs and HAs reported in other studies, as shown in the legend. Experimental conditions differ for each study and are listed in Supplementary Table S2. Key: SRFA, Suwanee River Fulvic Acid; LFFA, Lake Fryxell Fulvic Acid; KSW, K12.1, K10.2 and K8.3 are Bangladesh FAs described in Mladenov et al. (2015); SDFA, San Diego Bay Sediment Fulvic Acid; NLFA, Nymph Lake Sediment Fulvic Acid; 
SRHA, Suwanee River Humic Acid; SHHA, Summit Hill Humic Acid; PHA, Peat Humic Acid; LHA, Leonordite Humic Acid; SHA, Soil Humic Acid.

Reasons for high electron accepting capacity in humic and fulvic acids were previously explored by Scott et al. (1998). Using electron spin resonance, Scott et al. demonstrated that organic radical content (semiquinones) and stability of the semiquinone molecule are important determinants of electron accepting capacity. Although we were not able to measure semiquinone content in our BFA samples, the ${ }^{13} \mathrm{C}-\mathrm{NMR}$ functional group analyses of the BFAs used in this study (previously described in Mladenov et al., 2015) and other humic and fulvic acids (Thorn et al., 1991; Aiken et al., 1996; Scott et al., 1998) may provide additional support for their high electron accepting capacities (Table 1). Scott et al. (1998) demonstrated that higher molecular weight humic acids containing more aromatic structures may stabilize the unpaired electrons in the radical. Indeed, for the BFAs used in this study and other previously analyzed humic and fulvic acids, we found that aromaticity (Mladenov et al., 2015) and electron accepting capacity (this study) were highly correlated $\left(\mathrm{R}^{2}=0.73\right.$; Figure 4), consistent with similar observations by Scott et al. (1998). Nevertheless, the aromaticity of SRFA is as high as that of BFAs (Mladenov et al., 2015), yet the BFAs had higher electron accepting capacities than SRFA. This difference may be due in part to the sedimentary sources (described above) and the lower $\mathrm{C}: \mathrm{N}$ ratio of the BFAs (Table 1). Low $\mathrm{C}: \mathrm{N}$ ratios have been reported for organic matter in high As groundwater and found to enable faster As mobilization from iron oxyhydroxides than groundwater with higher C:N ratios (Solaiman et al., 2009). The chemical characteristics that are responsible for higher electron accepting capacities of BFAs are a question for further study.

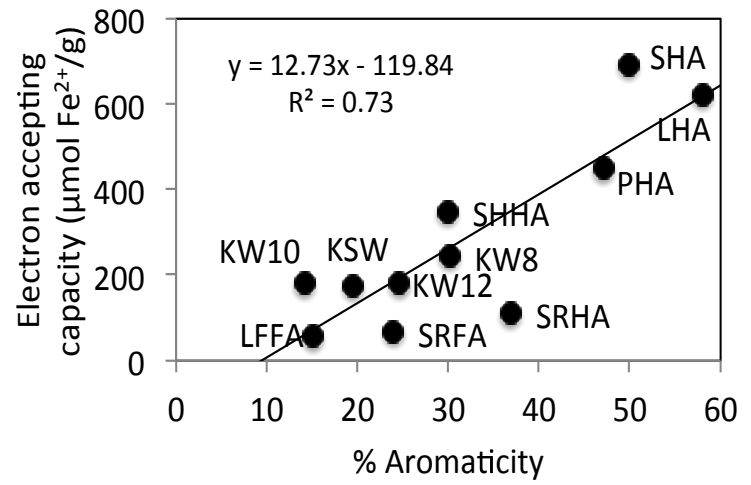

Figure 4. Scatterplot showing electron accepting capacity of all fulvic acids described in Table 1 plotted against $\%$ aromaticity.

In addition, when the $\mathrm{C}$ content of each fulvic acid is accounted for, results further show that BFAs had electron accepting capacities (on a per mol $\mathrm{C}$ basis) that were the same as or higher than fulvic acids isolated from highly reducing sediments, such as SDFA and NLFA, and some humic acids (Figure 3b). Interestingly, the amount of $\mathrm{Fe}(\mathrm{II})$ produced per mol $\mathrm{C}$ increases linearly from KSW and K12.1, the two samples with the lowest dissolved As concentration ( 0.0 to $69 \mathrm{ppb}$ ), to K8.3, the sample with the highest dissolved As concentration of $363 \mathrm{ppb}$ (Mladenov et al., 2015). These results further highlight that even groundwater FAs with a low $\% \mathrm{C}$ can stimulate electron shuttling and $\mathrm{Fe}$ (III) reduction as long as the electron accepting capacity of the FA is high. 


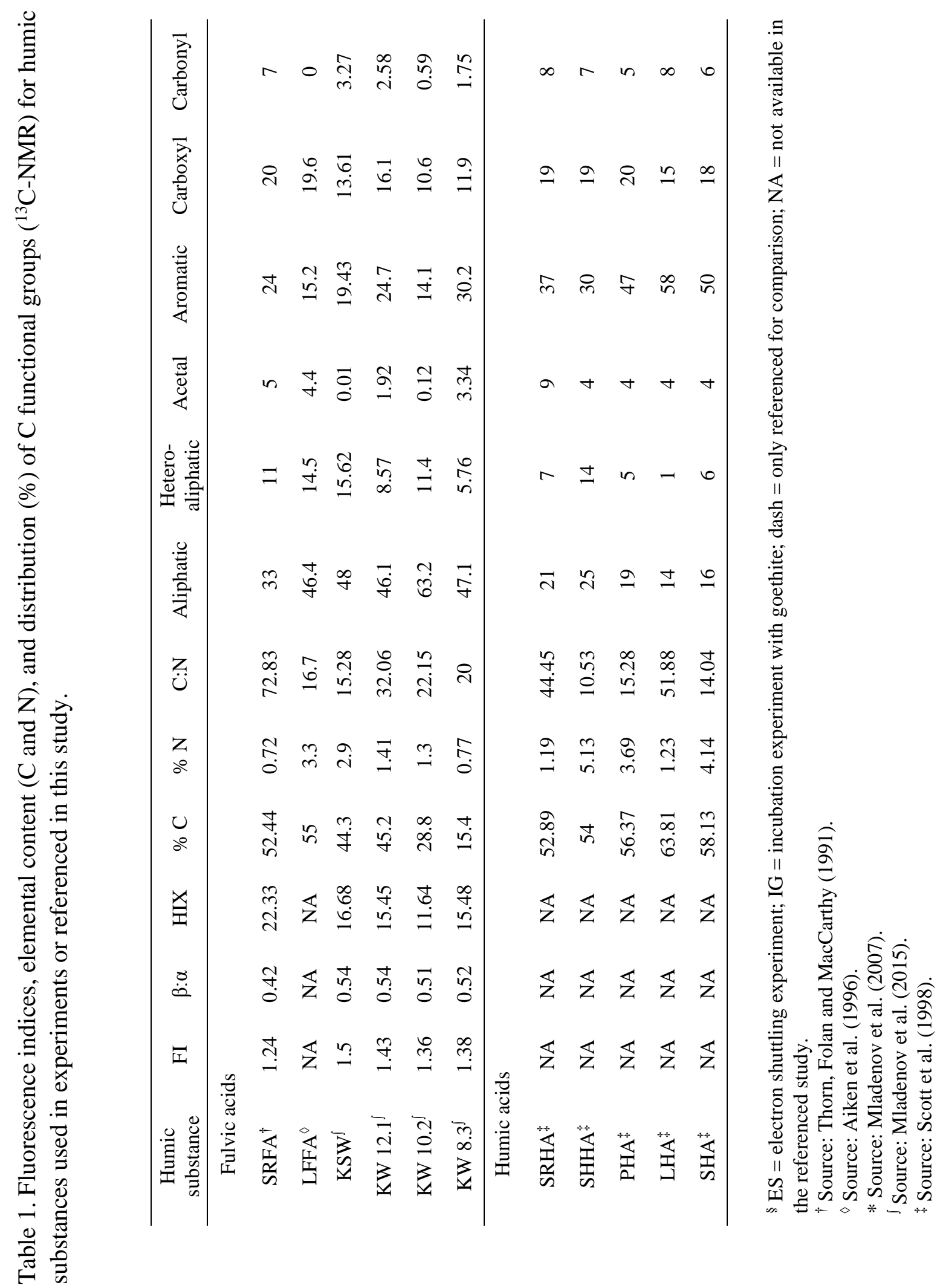


The two key findings of this study, that BFAs serve as electron shuttles in microbial Fe reduction and that BFAs have the capacity to substantially enhance Fe(III) reduction compared to AQDS and previously studied aquatic FAs, have important implications for our understanding of As mobilization in reducing aquifers. Several studies have now provided important field evidence that humic substances are integral to $\mathrm{Fe}$ and $\mathrm{As}$ mobilization. Chang et al. (2016) demonstrated that humic acid acquired from Aldrich and added to Fe-containing sediments from an As-affected area were able to mobilize ferrous iron only when bacteria, such as Geobacter sp., are present, and not in their absence. Gillaspie et al. (2016) further showed that the addition of Suwanee River humic and fulvic acids and labile OM to As-containing sediments in Cambodia produced much higher cumulative As release than incubations with only labile OM. Similarly Chen et al. (2017) found that $\mathrm{Fe}$ and As release was higher in sediment incubations when humics were added alongside microorganisms and labile OM than when humics were not included. Although these studies demonstrated that AQDS, SRFA, and commerciallymanufactured humic acid, acting as electron shuttles, were critical to the release of both $\mathrm{Fe}$ and As from sediments, no study has yet shown that native humic substances isolated from high As groundwaters are capable of fulfilling this role. Our process level understanding of the electron shuttling role of fulvic acids isolated from Bangladesh groundwater provides experimental support for the findings of the aforementioned studies.

The source of humic substances in Bangladesh aquifers and other high-As reducing aquifers is also of critical importance. The connection to sedimentderived, dissolved fulvic acids made by this study, therefore, may add to our understanding of the patchy nature of high
As concentrations that has been widely observed in studies of arsenic contamination in the Bengal Basin (Weinman et al., 2008; Fendorf et al., 2010) and elsewhere.

\section{References}

Aiken, G., McKnight, D., Harnish, R., \& Wershaw, R. 1996. Geochemistry of aquatic humic substances in the Lake Fryxell Basin,

Antarctica. Biogeochemistry, 34(3), 157-188.

Aziz, Z., Bostick, B.C., Zheng, Y., Huq., M.R., Rahman., M.M., Ahmed, K.M., van Geen, A., 2004. Evidence of decoupling between arsenic and phosphate in shallow groundwater of Bangladesh and potential implications. Applied Geochemistry. 77, 167-177.

Chakraborti, D. et al. Status of groundwater arsenic contamination in the state of West Bengal, India: A 20-year study report. Mol. Nutr. Food Res. 53, 542551 (2009).

Chang, C.H., Wei, C.C., Lin, L.H., Tu, T.H. and Liao, V.H.C. 2016. Humic acids enhance the microbially mediated release of sedimentary ferrous iron. Environmental Science and Pollution Research, 23(5), 4176-4184.

Chen, Z., Wang, Y., Jiang, X., Fu, D., Xia, D., Wang, H., Dong, G., Li, Q. 2017. Dual roles of AQDS as electron shuttles for microbes and dissolved organic matter involved in arsenic and iron mobilization in the arsenic-rich sediment. Science of the Total Environment, 574(422), 1684-1694.

Dowling, C. B., Poreda, R., Basu, A., Peters, S., Aggarwal, P. 2002. Geochemical study of arsenic release mechanisms in the Bengal Basin groundwater. Water Resour. Res. 38, 1-18.

Fendorf, S., Michael, H., van Geen, A. 2010. Spatial and temporal variations of groundwater arsenic in South and Southeast Asia. Science 328.5982, 1123 1127.

Flanagan, S.V., Johnston, R., Zheng, Y. 2012. Arsenic in tube well water in Bangladesh: health and economic impacts and implications for arsenic mitigation. Bulletin of the World Health Organization 90, 839-846.

Gillispie, E.C., Andujar, E., Polizzotto, M.L. 2016. Chemical controls on abiotic and biotic release of geogenic arsenic from Pleistocene aquifer sediments to groundwater. Environmental Science: Processes \& Impacts, 18(8), 1090-1103. 
Hasan, M. A., Ahmed, K.M., Sracek, O., Bhattacharya, P., von Brömssen, M., Broms, S., Fogelström, J., Mazumder, M.L., Jacks, G. 2007. Arsenic in shallow groundwater of Bangladesh: Investigations from three different physiographic settings. Hydrogeol. J. 15, 1507-1522.

Holmes, D. E., Bond, D.R., O’Neil, R.A., Reimers, C.E., Tender, L.R., Lovley, D.R. 2004. Microbial communities associated with electrodes harvesting electricity from a variety of aquatic sediments. Microb. Ecol. 48, 178-190.

Jiang, J. \& Kappler, A. 2008. Kinetics of microbial and chemical reduction of humic substances: implications for electron shuttling. Environ. Sci. Technol. 42, 3563-9.

Kappler, A., Benz, M., Schink, B., Brune, A. 2004. Electron shuttling via humic acids in microbial iron (III) reduction in a freshwater sediment. FEMS Microbiol. Ecol. 47, 85-92.

Legg, T., Zheng, Y., Simone, B., Radloff, K.A., Mladenov, N., Gonzalez, A., Knights, D., Siu, H.C., Rahman, M.M, Ahmed, K.M., McKnight, D.M., Nemergut, D.R. 2012. Carbon, metals, and grain size correlate with bacterial community structure in sediments of a high arsenic aquifer. Frontiers in Microbiology, 3, 82.

Lovley, D. R., Giovannoni, S. J., White, D. C., Champine, J. E., Phillips, E. J. P., Gorby, Y. A., \& Goodwin, S. 1993. Geobacter metallireducens gen. nov. sp. nov., a microorganism capable of coupling the complete oxidation of organic compounds to the reduction of iron and other metals. Archives of microbiology, 159(4), 336-344.

Lovley, D. R., Coates, J.D., Blunt-Harris, E.L., Phillips, E.J.P, Woodward, J.C. 1996. Humic substances as electron acceptors for microbial respiration. Nature 382, 445-448.

Lovley, D. R., Fraga, J.L., Blunt-Harris, E.L., Hayes, L.A., Phillips, E.J.P., Coates, J.D. 1998. Humic Substances as a Mediator for Microbially Catalyzed Metal Reduction. Acta Hydrochim. Hydrobiol. 26, 152-157.

Lovley, D. R., Fraga, J.L., Coates, J.D., Blunt-Harris, E.L. 1999. Humics as an electron donor for anaerobic respiration. Environ. Microbiol. 1, 89-98.

McArthur, J. M., Ravenscroft, P., Safiulla, S., Thirlwall, M.F. 2001. Arsenic in groundwater: Testing pollution mechanisms for sedimentary aquifers in Bangladesh. Water Resour. Res. 37, 109117.
Mladenov, N., Zheng, Y., Miller, M.P., Nemergut, D.R., Legg, T., Simone, B., Hageman, C., Rahman, M.M., Ahmed, K.M., McKnight, D.M. 2010.

Dissolved organic matter sources and consequences for iron and arsenic mobilization in Bangladesh aquifers. Environ. Sci. Technol. 44, 123-8.

Mladenov, N., Zheng, Y., Simone, B., Bilinski, T.M., McKnight, D.M., Nemergut, D.R., Radloff, K.A., Rahman, M.M., Ahmed, K.M. 2015. Dissolved Organic Matter Quality in a Shallow Aquifer of Bangladesh: Implications for Arsenic Mobility. Environ. Sci. Technol, 49(18), 10815-10824.

Neumann, R. B., Pracht, L.E., Polizzotto, M.L., Badruzzaman, B.M., Ali, M.A. 2014. Biodegradable Organic Carbon in Sediments of an ArsenicContaminated Aquifer in Bangladesh. Environ. Sci. Technol. Lett. 1, 221-225.

Nickson, R., McArthur, J., Burgess, W., Ahmed, K.M., Ravenscroft, P., Rahmann, M. 1998. Arsenic poisoning of Bangladesh groundwater. Nature, 395(6700), 338.

Radloff, K.A., Zheng, Y., Stute, M., Weinman, B., Bostick, B., Mihajlov, I., Bounds, M., Rahman, M.M., Huq, M.R., Ahmed, K.M. 2015. Reversible adsorption and flushing of arsenic in a shallow, Holocene aquifer of Bangladesh. Applied Geochemistry, 77, 142-157.

Reza, a. H. M. S., Jean, J., Lee, M., Liu, C., Bundschuh, J., Yang, H., Lee, J., Lee, Y. 2010. Implications of organic matter on arsenic mobilization into groundwater: Evidence from northwestern (Chapai-Nawabganj), central (Manikganj) and southeastern (Chandpur) Bangladesh. Water Res. 44, 5556-5574.

Roden, E. E. and Urrutia, M. M. 1999. Ferrous iron removal promotes microbial reduction of crystalline iron(III) oxides. Environ. Sci. Technol. 33, 18471853.

Roden, E. E. and Urrutia, M. M. 2002. Influence of biogenic $\mathrm{Fe}(\mathrm{II})$ on bacterial crystalline $\mathrm{Fe}(\mathrm{III})$ oxide reduction. Geomicrobiol. J. 19 (2), 209-251.

Roden, E. E., Kappler, A., Bauer, I., Jiang, J., Paul, A., Stoesser, R., Konishi, H., Xu, H. 2010. Extracellular electron transfer through microbial reduction of solid-phase humic substances. Nat. Geosci. 3, 417-421.

Scott, D. T., McKnight, D.M., Blunt-Harris, E.L., Kolesar, S.E., Lovley, D.R. 1998. Quinone Moieties Act as Electron Acceptors in the Reduction of Humic 
Substances by Humics-Reducing Microorganisms. Environ. Sci. Technol. 32, 2984-2989.

Simone, B. 2010. The role of dissolved organic matter in arsenic mobilization in groundwaters of Bangladesh. MS Thesis. University of Colorado at Boulder.

Solaiman, A.R.M., Meharg, A.A., Gault, A.G. and Charnock, J.M. 2009. Arsenic mobilization from iron oxyhydroxides is regulated by organic matter carbon to nitrogen $(\mathrm{C}: \mathrm{N})$ ratio. Environ. International, 35(3), pp.480-484.

Stookey, L. L. 1970. Ferrozine - a new spectrophotometric reagent for iron. Anal. Chem. 42, 779-781.

Thorn, Kevin A., Daniel W. Folan, and Patrick MacCarthy. 1991. Characterization of the International Humic Substances Society standard and reference fulvic and humic acids by solution state carbon-13 (13C) and hydrogen-1 (1H) nuclear magnetic resonance spectrometry. US Department of the Interior, US Geological Survey.

Urrutia, M. M., Roden, E.E., Zachara, J.M. 1999. Influence of aqueous and solid-phase Fe(II) complexants on microbial reduction of crystalline iron(III) oxides. Environ. Sci. Technol. 33 (22), 4022-4028.

Weinman, B., S. L. Goodbred, Y. Zheng, Z. Aziz, M. Steckler, A. van Geen, A. K. Singhvi, and Y. C. Nagar. 2008. Contributions of floodplain stratigraphy and evolution to the spatial patterns of groundwater arsenic in Araihazar, Bangladesh, Geological Society of America Bulletin, 120(11-12), 1567-1580.

Wrighton, K. C., Agbo, P., Warnecke, F., Weber, K.A., Brodie, E.L., DeSantis, T.Z., Hugenholtz, P., Andersen, G.L., Coates, J.D. 2008. A novel ecological role of the Firmicutes identified in thermophilic microbial fuel cells. ISME J. 2, 11461156.
Wolf, M., Kappler, A., Jiang, J., Meckenstock, R.U. 2009. Effects of humic substances and quinones at low concentrations on ferrihydrite reduction by Geobacter metallireducens. Environ. Sci. Technol. $43,5679-85$.

Zheng, Y., Stute, M., van Geen, A., Gavrieli, I., Dhar, R., Simpson, H.J., Schlosser, P., Ahmed, K.M. 2004. Redox control of arsenic mobilization in Bangladesh groundwater. Applied Geochemistry 19, 201-214.

\section{Acknowledgements}

This work was supported by grants from the US National Science Foundation (CBET \#1449247 and EAR \#0738888). We thank F. Pinongcos, B. Simone, T. Bilinski, and J. Wasswa for laboratory assistance. McKnight acknowledges support for independent research while a program officer at the National Science Foundation.

\section{Author contributions}

N.M., D.M.M., D.N. and Y.Z. conceived the electron shuttling project and H.K. and M.K. conceived the solid-phase reduction project. H.K. conducted laboratory analyses, geochemical modeling, and analyzed the data. H.K. and N.M. wrote the paper with input from all authors.

\section{Additional information}

Supplementary information accompanies this paper.

\section{Competing Financial Interests}

The authors declare no competing financial interests. 